The General Assembly, Vol. 2, No. 1, Jan. 2021

\title{
The Domestic and Geopolitical Ramifications of the Vietnam War on South Korea
}

Jade Sears

ABSTRACT The Vietnam War is a widely examined topic in the field of international relations. However, it is often viewed in terms of the strategic triangle between the United States, China, and the Soviet Union, instead of their allies. While the atrocities committed by the United States in the Vietnam War are often condemned and scrutinized in English literature, those of South Korea, their closest ally, remain less so. This essay outlines the South Korean government's political, economic, and ideological reasons for supporting the United States in Vietnam, the positive and negative consequences of this support, and the atrocities Korean troops committed against Vietnamese civilians. It argues that the legacy of the Vietnam War in South Korea is characterized by denial and neglect to this day. This essay finds that denial and neglect were experienced not only in Vietnam, but also in South Korea by veterans and the Korean government.

\section{Introduction and Argument}

Just over one decade after Korea's civil war ended, South Korea joined the United States in another ideological conflict against Vietnam. This time, however, Korea was determined to be the saviour instead of the victim and a champion of freedom and democracy against the communist contagion. Yet South Korea did not live up to these ideals. Not only did the South Vietnamese government fall to the communist North, but the Korean army also acted as little more than mercenaries and perpetrators of atrocities against the Vietnamese people. Korea reaped the political and economic benefits of the Vietnam War, positioning itself as a respectable nation on the international stage, while massacring and abusing Vietnamese civilians. In 1964, South Korea's authoritarian leader Pak Chong-hui offered the United States help in the Vietnam War during American president Lyndon Johnson's "More Flags" campaign. After identifying Pak Chong-hui's motivations for Korean involvement in Vietnam and its contribution, this essay will outline how South Korean citizens felt about the war, its economic, international, and geopolitical impacts on Korea, Korean atrocities perpetrated in Vietnam, and the impacts of Korean involvement on Korean-American relations. The legacy of the Vietnam War in South Korea and Vietnam is characterized by denial and neglect.

Pak Chong-hui offered substantial military aid to the United States in Vietnam, contributing the largest non-American task force. The Korean public did not support joining the war, as shown by the National Assembly, requiring Pak Chong-hui to embark on a crusade of 
militarization, propaganda, and censorship. The Vietnam War boosted Korea's economy and international reputation but also encouraged North Korean belligerence in the raid on the Blue House and the seizure of USS Pueblo in January 1968. Korean atrocities in Vietnam included the massacre of unarmed civilians, sexual abuse, and racism. These atrocities induced Vietnamese mourning, the spread of sexually transmitted diseases, and the ostracization of mixed-race children. South Korean-American relations improved exponentially at the beginning of the two countries' cooperation in 1964 but slowly degraded as the United States placed greater importance on its relations with Vietnam over its relations with Korea.

\section{Why South Korea Entered the Vietnam War}

\section{Political Motivations}

Pak Chong-hui had political, economic, and ideological motivations for offering Korean military assistance to the United States in Vietnam. Pak came to power through a military coup in 1961, toppling the parliamentary democracy of Chang Myon. He led a military government until 1963 when he held, ran, and emerged victorious in a presidential election, and subsequently established the Third Republic. Whether or not the election was legitimate, Pak was perceived by the Korean public as a military dictator who crushed the beginnings of a democratic Korea. By 1964, he faced strong opposition from the National Assembly ${ }^{1}$ and from student demonstrations, which almost toppled his government. ${ }^{2}$

In exchange for American support for his regime, Pak provided military aid to the American campaign in Vietnam. This exchange was desirable to the United States because it ensured that American intervention did not appear to be self-interested. South Korean support gave the campaign the semblance of a joint effort to protect Vietnamese freedom in the face of communist aggression. ${ }^{3}$ Pak also wanted to prevent American evacuation from Korea, as American military commitment to South Korean security had been declining steadily since the

\footnotetext{
${ }^{1}$ Se Jin Kim, "South Korea's Involvement in Vietnam and Its Economic and Political Impact," Asian Survey 10, no. 6 (1970): 525.

${ }^{2}$ Kil J Yi, "Alliance in the Quagmire: The United States, South Korea, and the Vietnam War, 1964-1968," (PhD diss., University of New Jersey: New Brunswick, 1997): 5.

${ }^{3}$ Charles K. Armstrong, “America's Korea, Korea's Vietnam,” Critical Asian Studies 33, no. 4 (2001): 533.
} 
end of the Korean War. ${ }^{4}$ Preventing American disengagement would increase public support for Pak and help him consolidate his regime.

\section{Economic Motivations}

Pak Chong-hui also deployed Korean troops to Vietnam to prop up the Korean economy. He sought the economic benefits of going to war which would consolidate his regime, paralleling Japan's dramatic accumulation of wealth during the Korean War. ${ }^{5}$ Pak wanted to expand South Korean exports to South Vietnam and their allies, as well as gain access to commercial opportunities in South Vietnamese markets. Additionally, he wanted access to American agricultural aid through PL 480, a program that would allow South Korea to purchase American agricultural goods with their own currency instead of foreign exchange. ${ }^{6}$ South Korea faced several issues that stunted its economic development, such as the lack of domestic capital, foreign investments, and job opportunities. The government had little money for capital investment because Koreans consumed more than they produced, requiring the South Korean government to use foreign aid to meet consumption needs.

The political and social instability of the first two republics combined with the threat of North Korea provided additional barriers to foreign investment. In the aftermath of the Korean War, South Korea's economy was in ruins and dependent on the United States for financial assistance. South Korean politics were dominated by Syngman Rhee, an authoritarian leader who was more concerned with staying in power than with pulling South Korea out of poverty or creating a stable political system. ${ }^{7}$ Rhee resigned in 1960 under immense pressure from student demonstrations and the United States. ${ }^{8}$ He was succeeded by the Second Republic of Chang Myon, whose ineffective attempt at a democratic government lead to instability, inflation, and constant student demonstrations. Moreover, the instability of the previous two South Korean republics exacerbated the fear of a North Korean invasion. ${ }^{9}$ The combination of the political and social instability of South Korea under the Rhee and Myon administrations and fear of a North Korean invasion drove away foreign investment in the South.

\footnotetext{
${ }^{4}$ Glenn Baek, “A Perspective on Korea's Participation in the Vietnam War,” The Asian Institute for Policy Studies, no. 53 (April 2013): 6.

5 Yi, “Alliance in Quagmire," 147.

${ }^{6}$ Ibid., 138-139.

${ }^{7}$ Michael J. Seth, A Concise History of Korea: From Antiquity to the Present (New York: Rowman \& Littlefield, 2016), 400.

${ }^{8}$ Seth, A Concise History of Korea, 402.

${ }^{9}$ Seth, A Concise History of Korea, 404.
} 
South Korea also lacked job opportunities for those who were educated or trained, which fostered social discontent in a population that was either under or unemployed. The government exacerbated the country's unemployment through its inflationary monetary policies. ${ }^{10}$ Intervening in Vietnam was perceived to be a solution to Korea's economic woes as it would provide extra capital through exports and commercial opportunities, as well as open the country up to greater capital through PL 480. ${ }^{11}$ Finally, educated Koreans would be able to exercise their training in Vietnam through the creation of an abundance of skilled jobs, such as engineering or medicine, thereby reducing social discontent.

\section{Ideological Motivations}

Anti-communism was the primary justification Pak gave to the South Korean public for entering the Vietnam War. He drew parallels between the Vietnamese and Korean contexts, claiming that if South Vietnam was conquered by the North, North Korea might be emboldened to attack the South. With the memory of the Korean War still prominent in the public mind, Pak's reasoning proved effective in justifying intervention in the name of freedom. The South Korean public displayed their support for Pak and his ideological narrative concerning Vietnam through the absence of anti-government demonstrations, which he had experienced in his first election in 1964, and his re-election in 1967. Pak won the 1967 election over his opponent Bo-sun Yun by a landslide despite Yun's constant criticism of Pak's Vietnam policy. Support for his government among military personnel increased from 32-40 percent in 1963 to 60-65 percent in the 1967 election. $^{12}$

It is possible that Pak did not genuinely believe in his own anti-communist rhetoric, using it as political propaganda, but this does not mean communism was not a real concern. Surrounded by communist China, the USSR, and North Korea, Pak was aware of the danger that a communist Vietnam would pose to his regime. Therefore, even if his anti-communist rhetoric was a propaganda tool designed to win domestic support, Pak had a valid geopolitical interest in supporting the democratic South Vietnamese government. Additionally, Pak would have considered the training and combat experience gained in Vietnam valuable in the event of a

${ }^{10} \mathrm{Yi}$, “Alliance in Quagmire," 140-141.

11 Ibid., 99.

12 Jin-kyung Lee, "Surrogate Military, Subimperialism, and Masculinity: South Korea in the Vietnam War, 1965-73,” Positions: East Asia Cultures Critique 17, no. 3 (2009): 658. 
future North Korean invasion. ${ }^{13}$ Furthermore, Pak wanted to demonstrate capitalism's superiority relative to communism by reaping the war's economic benefits. Since the end of the Korean War, South Korea had lagged behind the North economically and militarily, producing doubt in the Western model of development amongst intellectuals and students. ${ }^{14}$ The economic boost provided by engagement in Vietnam would allow Pak to further develop the country's economy and assuage these doubts.

\section{$\underline{\text { South Korea's Commitment to the Vietnam War }}$}

In the past, South Korea had offered military assistance to the United States and France in Vietnam, beginning in 1954 under Syngman Rhee's administration. However, due to the nation's instability and its military's vulnerable condition, the United States turned down Rhee's proposal lest North Korea or China take advantage of its weakened state. During Pak Chong-hui's military regime, South Korea became more stable and the United States more desperate. ${ }^{15}$ The United States needed more foreign troops in Vietnam as the conflict escalated, and a surrogate Korean army fulfilled this need. Korean soldiers were paid less than their American counterparts and were already staunchly anti-communist due to their experiences during the Korean War. ${ }^{16}$ By using Korean troops, the United States would save on resources and expenses since they would not have to justify the war to Korean soldiers. The United States had attempted to recruit other nations during Johnson's "More Flags" campaign with threats, economic enticements, and appeals, but only Australia, New Zealand, the Philippines, Thailand, and South Korea responded favourably. ${ }^{17}$

The first few years of Korean involvement in Vietnam required a relatively low level of commitment, which would increase dramatically in 1966 with the Brown Memorandum. The National Assembly, a South Korean governing body, was pressured into approving Korea's first deployment of non-combat troops at the end of July $1964^{18}$ and the Mobile Army Surgical

\footnotetext{
${ }^{13}$ Jin-kyung Lee, "Surrogate Military," 658.

${ }^{14} \mathrm{Yi}$, "Alliance in Quagmire," 6.

15 Armstrong, “America's Korea," 532.

${ }^{16}$ Lee "Surrogate Military," 663.

${ }^{17}$ Frank Baldwin, "America's rented troops: South Koreans in Vietnam," Bulletin of Concerned Asian

${ }^{18}$ Benjamin A. Engel, "Viewing Seoul from Saigon: Withdrawal from the Vietnam War and the Yushin Regime," The Journal of Northeast Asian History 13, no. 1 (2016): 87.
} Scholars 7, no. 4 (1975): 33. 
Hospital and ten Taekwondo instructors in September. ${ }^{19}$ Next was the "Dove Unit," a group of 2,000 men consisting mostly of army engineers, in February $1965 .{ }^{20}$ South Korea's first deployment of combat troops began with 15,000 troops in the elite "Fierce Tiger" division and 5,000 "Blue Dragon" elite marine troops in $1965 .{ }^{21}$ By 1966, the United States was desperate for more Korean troops, which strengthened South Korea's bargaining power. Pak's government received written assurances that its national security would not be threatened by sending more troops to Vietnam, and American commitment would not be reduced without consultation. In March 1966, it also obtained the Brown Memorandum, which granted considerable economic concessions to Korea in exchange for almost 24,000 troops. $^{22}$

Thereafter, Korean commitment increased until the 1970s when the Pak government tried to withdraw from Vietnam. Despite these efforts, the Korean army remained stationed in Vietnam until January 1973, after the Paris Peace Accords was reached. ${ }^{23}$ Their area of operations extended from the southern Cam Ranh Bay to Qui Nhon in the North. Korean armed forces garnered a reputation over the course of the conflict as being ferocious and effective in tough pacification efforts. ${ }^{24}$ American personnel claimed they outperformed other allied troops in organization, professionalism, and lethality. ${ }^{25}$

\section{South Korean Opposition to Participation in the War}

\section{Opposition in the National Assembly and Pak Chong-hui's Response}

South Korea's National Assembly listed several reasons why it opposed Pak's commitment in Vietnam by 1966. It cited security concerns over the overseas deployment of elite divisions, an escalation of tensions with North Korea, high economic and human costs, the corruption between government and business through lucrative contracts, and the entrenchment of Pak's military regime. ${ }^{26}$ The National Assembly also criticized what they perceived as Pak's poor diplomatic skills, which resulted in the higher ratio of American resource procurements from Japan compared to Korea despite Japan giving no military aid to the United States in

\footnotetext{
19 Armstrong, “America's Korea,” 532.

${ }^{20}$ Engel, "Viewing Seoul", 88.

21 Armstrong, "America's Korea," 532.

22 Baldwin, “America's Rented Troops,” 35-36.

${ }^{23}$ Engel, "Viewing Seoul," 97.

24 Armstrong, "America's Korea," 532.

${ }^{25}$ Baek, "A Perspective," 3.

${ }^{26}$ Kim, "South Korea’s Involvement," 524-525.
} 
Vietnam. ${ }^{27}$ These concerns were addressed in the 1966 Brown Memorandum, ${ }^{28}$ in which Pak secured his domestic position by taking advantage of the United States' desperation for additional troops, thereby addressing the National Assembly's critiques and growing popular support for his military regime.

The National Assembly was justified in its fear of Pak's entrenchment, the cost of Korean lives, and the war's economic drive. As his militarization efforts strengthened national cohesion and patriotism, support for Pak's regime grew and created political stability. ${ }^{29}$ The cost in human lives was also significant, as Korea lost 2,980 soldiers by $1969 .{ }^{30}$ Other casualties came from tropical diseases for which the Pak government failed to adequately prepare the soldiers.

Each soldier received a handbook titled Introduction to Vietnam that detailed a wide range of topics, including why Korea joined the Vietnam War, the climate, history, and culture of Vietnam, a rudimentary Vietnamese vocabulary, and advice on public health and hygiene. ${ }^{31}$ Despite dedicating an entire section to the ideological narrative that South Korea needed to protect Northeast Asia's security through the Vietnam conflict, the handbook condensed crucial information concerning how to identify tropical diseases. It provided soldiers with vague descriptions of only thirteen diseases that were not accompanied by visual aids. As most Korean soldiers in Vietnam lacked a postsecondary education, the lack of visual aids and abundance of medical terminology prevented them from grasping understanding the contents of the handbook. ${ }^{32}$ In particular, malaria was one of the greatest dangers to South Korean troops in Vietnam. ${ }^{33}$ Pak used the Introduction to Vietnam to expound his ideological motives and entrench himself in Korea, even at the expense of properly educating his troops. The handbook supposedly acted as proof that the Pak government fulfilled their duty towards Korean soldiers even though it fell well short of this objective and was politically and ideologically motivated. ${ }^{34}$

${ }^{27}$ Ibid., 525.

${ }^{28}$ Baldwin, "America's Rented Troops," 36-37.

${ }^{29} \mathrm{Kim}$, "South Korea's Involvement," 527.

${ }^{30}$ Ibid., 526.

${ }^{31}$ Jane S. H. Kim, "Penile Necrosis, Military Medicine, and South Korean Participation in the Vietnam War, 1964-1973," East Asian Science, Technology and Society: An International Journal 11, no. 4 (2017): 549.

${ }^{32}$ Kim, "Penile Necrosis," 550.

${ }^{33}$ Ibid., 542.

${ }^{34}$ Kim, "Penile Necrosis," 551. 


\section{Pak Chong-hui's Militarization of the Korean Public}

To protect himself against public opposition, Pak implemented a system of militarization and propaganda while censoring negative accounts of the war. Militarization was undertaken through ceremonial sending-off and welcoming ceremonies for soldiers. ${ }^{35}$ These ceremonies were staged by the government, nationally broadcasted on radio and television, and publicized by newspapers. There were speeches by government officials, motorcades, soldiers marching through downtown Seoul being offered wreaths by entertainers, military marching songs, and tens of thousands of mobilized civilians and student participants. Schools, factories, and offices also adopted militaristic rituals. Nationalist and pro-war propaganda were used during these ceremonies to reinforce themes of militarization. Pak aired regular broadcasts in which he espoused the righteousness of the Vietnam War in the fight for freedom against aggressive communism. $^{36}$

Additionally, Pak tried to enhance national masculinity in his broadcasts by connecting it to military success. He recited the history of ancient Korea and the elite male corps of the Hwarang, encouraging soldiers to demonstrate Korean manhood in Vietnam. ${ }^{37}$ Pak's broadcast efforts were very effective; South Korea had been a subordinate nation under Japan since 1904 and the United States since 1945, and the Vietnam War offered the public a chance to reclaim its masculinity. In 1945, South Korea was freed from colonial subordination under Japan only to become politically, militarily, and economically subordinate to the United States. Pak used the emasculation that South Koreans endured during the previous 60 years to support his militarization campaign and to indoctrinate South Korean civilians. He tied military success in Vietnam with South Korea becoming an "adult" country that could reclaim its masculinity by helping another subordinate nation. ${ }^{38}$ Essentially, military success would enhance South Korea's self-confidence and national pride. ${ }^{39}$

\section{Pak Chong-hui's Censorship Campaign}

Public discussion about the Vietnam War did not arise until the 1990s. The South Korean media had been under strict censorship until the late 1980s to ensure the message of a just war

\footnotetext{
${ }^{35}$ Lee, "Surrogate Military," 659.

${ }^{36}$ Lee, "Surrogate Military," 659-660.

${ }^{37}$ Ibid.

${ }^{38}$ Lee, "Surrogate Military," 660-661.

${ }^{39}$ Kim, “South Korea’s Involvement," 527.
} 
was firmly entrenched in the Korean public's minds. This was done in part to prevent public criticism from harming South Korean-American relations and from exacerbating negative views on the financial costs of the war. ${ }^{40}$ The media reported solely on the troops' good deeds for Vietnamese civilians, including providing humanitarian aid, building infrastructure (e.g. roads, parks, schools, etc.), arranging entertainment for village seniors, and teaching Taekwondo. ${ }^{41}$ The censorship of opinion on the Vietnam War indoctrinated the Korean public into believing that South Korea was involved in the war solely for the defence of freedom against communist aggression and kept them ignorant of the atrocities committed by South Korean soldiers. ${ }^{42}$ Censorship by the South Korean media and government contributed to a legacy of denial concerning the Vietnam War in the public's collective memory.

\section{The Impacts of the Vietnam War on South Korea}

\section{Economic Impacts}

The Vietnam War improved South Korea's economy and international reputation, but it also encouraged North Korean belligerence. The South Korean economy received a muchneeded boost by the Vietnam War through the provisions of the Brown Memorandum. Economic concessions in the agreement included the modernization of weapons in Korea and Vietnam, payment of Korean troop deployment, salaries, death and disability benefits, favourable access to military procurement contract and exclusive access to contracts for the Agency of International Development in Vietnam for Korean firms, and increased technical assistance and loans to South Korea. $^{43}$

By assuming the costs of the modernization of Korean weapons and salaries in Vietnam, the United States alleviated some of the costs associated with military operations. Pak did not have to spend millions of dollars to match North Korea's military development or accumulate debt, like the United States did, to finance the war. The majority of Korean volunteers in Vietnam came from poor backgrounds and were enticed to join for economic gain. ${ }^{44}$ The pay provided by the United States for the lowest ranking private was twenty-three times his base pay

\footnotetext{
${ }^{40}$ Armstrong, “America's Korea,” 530-531.

${ }^{41}$ Lee, "Surrogate Military," 664.

42 Armstrong, "America's Korea," 531.

${ }^{43}$ Engel, "Viewing Seoul," 88.

${ }^{44}$ Lee, "Surrogate Military," 662.
} 
in Korea, ${ }^{45}$ resulting in a surplus of civilian capital and increased consumer demand that was previously unthinkable. ${ }^{46}$ Even though much of the earnings went to the informal economy, Korea's exchange holdings accrued steadily from \$138 million in 1965 to \$386 million in $1968 .{ }^{47}$ Capital also came from American troops in Korea, who used American currency. Between 1966 and 1972, South Korea earned $\$ 931.9$ million in foreign exchange from American forces. ${ }^{48}$ However, the surge of capital spurred inflation and the cost of living rose over 26 percent by 1968, negatively impacting those who did not share the wealth from Vietnam. ${ }^{49}$

The economic concessions of the Brown Memorandum jumpstarted both heavy and light industry in South Korea due to lucrative contracts included in the document. The increased circulation of currency that followed enhanced the nation's ability to increase imports and exports, providing the basis for obtaining greater foreign investments and loans. From 1965 to 1968, imports in South Korea rose 100 percent while exports rose by 300 percent. ${ }^{50}$ The Vietnam War accelerated industrialization, increasing Korea's growth rate from 7 percent to 12 percent by 1968. This rise was because of exclusive and preferential contracts given to Korean companies in Vietnam by the United States. Service contracts encompassed construction, engineering projects, transportation of goods, and operating service facilities. Major exports from military contracts consisted of military uniforms, boots, metal roofing, and cement. ${ }^{51}$

Throughout the 1960s and 1970s, the United States promised to purchase construction materials, raw blanket materials, petroleum, oil, and lubricants from Korean firms. ${ }^{52}$ Working with Pak's industrialization program, through which exports were expanded by particular firms while restricting imports, South Korea's GDP increased fourfold between 1963 and 1973. ${ }^{53}$ Heavy-industry companies were able to develop and expand, fuelling the rise of governmentsponsored conglomerates such as Samsung and Hyundai. ${ }^{54}$ South Korea's economic expansion of the 1960 and 1970s would not have transpired without its military involvement in Vietnam.

\section{International Impacts}

\footnotetext{
${ }^{45}$ Baldwin, “America's Rented Troops,” 38.

${ }^{46}$ Kim, "South Korea's Involvement," 521.

${ }^{47}$ Ibid., 519-520.

48 Baldwin, "America's Rented Troops," 40.

${ }^{49}$ Ibid., 533.

${ }^{50}$ Kim, "South Korea’s Involvement," 520-521.

${ }^{51}$ Baldwin, "America's Rented Troops," 39.

${ }^{52} \mathrm{Yi}$, "Alliance in Quagmire," 155.

${ }^{53}$ Baek, "A Perspective," 4.

54 Armstrong, "America’s Korea," 533.
} 
South Korea was lauded on the international stage due to its involvement in Vietnam alongside allied nations. For the first time since its independence, other countries considered Korea as a mature nation capable of discussing security and trade in international conferences. ${ }^{55}$ In June 1966, South Korea hosted and organized the Asian Pacific Conference, consisting of non-communist nations in Southeast and Eastern Asia, to forge new political, economic, and cultural bonds as well as to elicit support for American policy in Vietnam. ${ }^{56}$ The meeting was a success, impressing the United States and proving Korea's capability in organizing international forums. Korean representatives attended many conferences afterwards and acted as vocal opponents to peace negotiations with North Vietnam. ${ }^{57}$

South Korea had become a significant geopolitical actor in the eyes of its allies in the mid-1960s. Pak Chong-hui's second presidential inauguration in July 1967 boasted the most well-represented ceremony of important foreign dignitaries in Korean history up to that point. ${ }^{58}$ Furthermore, at the Honolulu conference in 1968, President Johnson travelled half-way across the world to meet Pak for the third South Korean-American summit, the leader of a country that the United States had viewed as a burden only a few years prior. ${ }^{59}$ Without the political and economic benefits derived from the Vietnam War, it seems unlikely South Korea could have achieved such a level of international prominence in such a short amount of time.

\section{Geopolitical Impacts}

Despite positive economic consequences, South Korea's involvement in the Vietnam War further exacerbated already tense relations with the North. North Korea prepared for their violation of the 1953 armistice by training 40,000 elite guerrilla troops, replacing top military personnel in Pyongyang, and provoking multiple skirmishes along the De-militarized Zone in 1967. In January 1968, the North shot down an unarmed American reconnaissance plane, ${ }^{60}$ infiltrated the South Korean Blue House in an attempt to assassinate Pak Chong-hui, and captured the USS Pueblo intelligence ship. ${ }^{61}$ These operations were undertaken to thwart South Korea's economic progress and political stability, as well as to strain South Korean-American

\footnotetext{
55 Baek, “A Perspective," 5-6.

${ }^{56} \mathrm{Kim}$, "South Korea's Involvement," 531.

${ }^{57}$ Baek, "A Perspective," 5-6.

${ }^{58} \mathrm{Kim}$, "South Korea's Involvement," 530.

${ }^{59}$ Ibid.

${ }^{60}$ Ibid., 527.

${ }^{61}$ Engel, "Viewing Seoul," 90.
} 
relations and resources with the possibility of a second front. The North feared that the Pak regime's industrial expansion would weaken its industrial superiority, especially since it had failed to fulfill its own Seven-Year Development Plan. ${ }^{62}$ North Korea faced no serious repercussions, much to Pak's chagrin, and the attacks succeeded in destabilizing South Korea's confidence in its security and in straining Korean-American relations.

However, North Korean belligerence was unsuccessful in that it boosted domestic support for Pak's regime and prompted increased South Korean militarization along the Demilitarized Zone. The South responded to North Korea's aggression with a massive expansion in its militia; by May 1968, the Homeland Reserve Forces numbered 2,500,000 in addition to its regular army of 600,000 troops. South Korean civilians rallied behind Pak Chong-hui, who had come to be associated with national prosperity and stability, thereby strengthening his popularity, intensifying anti-communist sentiments, and uniting the South against the North. ${ }^{63}$

\section{South Korean Atrocities in Vietnam}

South Korean atrocities in Vietnam included the massacre of unarmed civilians, sexual abuse, and racism. These crimes induced changes in Vietnamese mourning, the spread of sexually transmitted diseases, and the ostracization of mixed children. The massacre of unarmed civilians occurred in many Vietnamese villages during the war. One of the most well-known atrocities was committed in Ha My in February 1968, where South Korean Marine troops of the Blue Dragon division had been giving aid to Ha My through food and building resources after they resettled the village. ${ }^{64}$ Following the North Vietnamese Tet Offensive, the enemy army honoured Ha My for taking part in the resistance. This triggered a counterattack by the Korean army, which massacred six villages before reaching Ha My. On February 25, South Korean troops rounded up the villagers into three sites where the villagers, who thought they were receiving food, were gunned down. ${ }^{65}$ Of those killed, only three were men of combat age; the rest were women, elders, and children. ${ }^{66}$ The survivors tried to gather the dead, but the troops

${ }^{62}$ Kim, "South Korea’s Involvement," 527.

${ }^{63}$ Ibid., 528.

${ }^{64}$ Heonik Kwon, After the Massacre: Commemoration and Consolation in Ha My and My Lai (Berkeley: University of California Press, 2006), 31.

${ }^{65} \mathrm{Kwon}$, After the Massacre, 44-45.

${ }^{66}$ Ibid., 45. 
returned, flattened the houses, and destroyed the shallow graves dug by the villagers and the bodies in them. ${ }^{67}$

Korean massacres severely altered Vietnamese mourning while inducing the creation of revenge stories. Survivors remember the desecration of their dead as being the most atrocious part of the massacre. Ha My residents were unable to identify their dead as they were forced from the village while the bodies decomposed before they returned. ${ }^{68}$ Vietnamese villagers believed that such a violent death, along with the improper mass grave, subjugated the victims' souls to relive the incident forever unless a reburial was performed to separate the soul from the event. ${ }^{69}$ The distress felt by the villagers due to this belief sparked a revival of ancestral tombs in the 1990s and the adaptation of traditional tombs by adding an external shrine for displaced souls. ${ }^{70}$ Vengeance stories were created as a coping mechanism to give the victims a sense of justice, such as angry ancestors causing soldiers to go insane or die. ${ }^{71}$ Korean troops committed many more massacres during their time in Vietnam like Ha My, as well as random and indiscriminate killings which had similar impacts on the Vietnamese population.

Sexual assault against Vietnamese civilians was yet another tragic reality of the Vietnam War. ${ }^{72}$ Rape was a tactic of psychological warfare used against North Vietnamese soldiers to "devalue" their women since they were seen as enemy property. ${ }^{73}$ Ahn Junghyo's White Badge depicts an incident of sexual assault where a female guerrilla fighter was captured and the Korean troops make lewd suggestions of searching her genitals for weapons. ${ }^{74}$ Junghyo's novel reveals the well-documented reality of sexual assault against Vietnamese women by South Korean soldiers during the war. ${ }^{75}$

Racism was an underlying motive behind these sexual assaults and civilian massacres. Anti-Vietnamese racism was prominent in Korean literature surrounding the Vietnam War, such as in Marine veteran Hwang Suk-Yong's Shadow of Arms. This novel shows the Korean

\footnotetext{
${ }^{67}$ Ibid., 46.

${ }^{68}$ Ibid., 120-121.

${ }^{69}$ Ibid., 121.

${ }^{70}$ Kwon, After the Massacre, 105-106.

${ }^{71}$ Ibid., 107.

${ }^{72}$ Lee Kim, "Korea's Vietnam Question," 628.

${ }^{73}$ Lee, "Surrogate Military," 671.

${ }^{74}$ Ibid., 670.

75 Ibid., 671.
} 
adoption of American racial terms like "gooks" first-used during the Korean War. ${ }^{76}$ In othering the Vietnamese and portraying them as inferior, Korean soldiers justified their horrendous acts against them. Soldier's wages were another factor behind the sexual assaults. Salaries were low among the lowest ranks in the army, and what little extra they did have was often sent to their families. Consequently, few soldiers could afford prostitutes in Vietnam. ${ }^{77}$ The inability to purchase sex, combined with the racist belief of the Vietnamese as lesser, apparently influenced many Korean soldiers to sexually abuse Vietnamese civilians during pacification efforts after 1967.

Regardless of Korean justifications, these sexual assaults produced many detrimental social and psychological consequences among Vietnamese villagers, including the transmission of venereal diseases and the ostracization of mixed children. The spread of sexually transmitted diseases was fostered by mass-unprotected sex through prostitution and rape. ${ }^{78}$ The Introduction to Vietnam handbook given to Korean soldiers in Vietnam by the South Korean government made no mention of venereal disease in the health section despite the prevalence of prostitution during the Vietnam War. Neither was there any mention of contraceptives for sexual activity in the supplements section. ${ }^{79}$ Additionally, it seems unlikely that soldiers who sexually abused civilians purchased and used contraceptives. Another consequence of the war was the conception of mixed Korean-Vietnamese children. They faced similar racial stigma to VietnameseAmerican and Korean-American children and were often abandoned by their fathers after the war. ${ }^{80}$ These children serve as an ongoing testament to the legacy of neglect in the Vietnam War.

\section{$\underline{\text { South Korean-American Relations due to Korean Involvement }}$}

\section{Relations between 1964-1968}

South Korean-American relations improved exponentially at the beginning of the war but slowly degraded as the United States prioritized their relations with Vietnam over those with Korean. Until 1968, Pak enjoyed a relatively close relationship with the administration of

\footnotetext{
${ }^{76}$ Viet Thanh Nguyen, Nothing Ever Dies: Vietnam and the Memory of War (Cambridge, Massachusetts:
} Harvard University Press, 2016), 140.

${ }^{77}$ Kim., "Penile Necrosis," 554.

${ }^{78}$ Ibid., 548.

${ }^{79}$ Ibid., 550-551.

${ }^{80}$ Armstrong, “America's Korea," 537. 
Lyndon Johnson, Korea being treated as an equal partner instead of a subordinate nation. ${ }^{81}$ South Korea had developed an unprecedented level of social and political stability alongside a spirit of self-respect and reciprocity, which the United States valued. It had transformed from a burdensome protectorate to an ally making significant contributions to a common anticommunist cause. ${ }^{82}$ The high point of South Korean-United States relations was in 1966 with the creation of the Brown Memorandum and the Status of Forces Agreement. ${ }^{83}$ The latter agreement recognized South Korea's administrative sovereignty over Vietnam's allied troops, exempting the Americans. ${ }^{84}$ Pak obtained promises from American representatives during summit meetings that South Korea would be informed and consulted on any prospective peace negotiations in Vietnam. The representatives also pledged to ensure Korean security. ${ }^{85}$

\section{Relations between 1968-1973}

As the war persisted, the United States started to place Vietnamese policy above that of Korea, reneging on their previous guarantees and making unilateral war decisions. Korean troops were ordered to avoid high Korean casualties, but Americans began to resent them, viewing them as difficult and inflexible as the American casualties mounted and the Korean troops stayed in their bases. ${ }^{86}$ A rift between the two nations was induced by the North Korean attacks of 1968. Pak Chong-hui was outraged by the ensuing attempt on his life and the blatant violations of the armistice agreement, demanding American support for retaliation. The United States refused as it did not desire a two-front war, and when Pak Chong-hui threatened to remove Korean troops from Vietnam, American ambassadors made it clear the United States would not permit that action. ${ }^{87}$ The United States then opened discussions with North Korea and pointedly did not include South Korea or make an issue out of the attacks. This was humiliating for Pak's administration and demonstrated President Johnson's willingness to put American interests in Vietnam ahead of the United States' relationship with Korean. ${ }^{88}$

The Nixon administration did little to endear themselves to Pak either. Richard Nixon won the American presidency in part by promising to conclude American involvement in the

\footnotetext{
${ }^{81}$ Baek, "A Perspective," 4-5.

${ }^{82}$ Kim, "South Korea's Involvement," 529.

${ }^{83}$ Engel, "Viewing Seoul," 88.

${ }^{84}$ Kim, "South Korea’s Involvement," 529-530.

${ }^{85}$ Ibid., 530.

${ }^{86}$ Baek, "A Perspective," 3.

${ }^{87}$ Engel, "Viewing Seoul," 89-90.

88 Yi, "Alliance in Quagmire," 155.
} 
Vietnam War. To fulfill this promise, he cut American commitment in Vietnam and Korea while normalizing relations with China. Both of these actions broke previous promises made to the South Korean government. Although Seoul was supposed to be informed of any peace negotiations involving Vietnam, Pak was forced to send his foreign minister to discover whether any deals were made concerning Korea in $1971 .{ }^{89}$ The South Korean government was also not consulted on the reduction of American commitment.

Pak and the South Korean government felt unappreciated by the United States and suspicious of their commitment to Korean security due to the China détente. South Korea had made the most significant commitment to American efforts in Vietnam out of those who answered the "More Flags" call for aid, yet the United States did not honour the agreements made for that support. The gradual American withdrawal from Vietnam later justified South Korean suspicion. Nixon threatened to further disengage troops from Korea should Pak withdraw from Vietnam and made unilateral Vietnam policy decisions. ${ }^{90}$

When American troops began withdrawing from Vietnam in 1972, they demanded that Korean troops leave their bases and proactively engage the enemy to enhance Vietnamization efforts. Vietnamization was a United States policy in which the South Vietnamese army was trained and given an increasing role in combat to counter American withdrawal. This generated a reversal in the ratio of Korean and American deaths. In 1968 the ratio was 14,561 American deaths to 663 Korean, while in 1972, it was 132 Americans to 380 Koreans. The pace of withdrawal was so imbalanced that the United States debated leaving American personnel to handle Korean logistical needs. Moreover, they discussed how to make the Korean government leave a division in Vietnam after peace negotiations were concluded. ${ }^{91}$ These examples further demonstrate that the United States put its Vietnam policy ahead of its alliance with South Korea and perpetuated the legacy of neglect in the Vietnam War.

\footnotetext{
${ }^{89}$ Engel, "Viewing Seoul," 83-84.

${ }^{90}$ Baek, "A Perspective," 5.

${ }^{91}$ Engel, "Viewing Seoul," 98-99.
} 


\section{The Legacy of South Korean Involvement in Vietnam after the War}

\section{Denial and Neglect in South Korea}

The legacy of the Vietnam War was that of denial and neglect on the part of the South Korean and Vietnamese governments and media since the withdrawal of Korean troops in 1973. Both the South Korean and Vietnamese governments ignored the past atrocities committed by Korean combatants, forgoing past animosity in favour of future economic benefit. The South Korean government sought to keep its lucrative contracts gained in the Vietnam War by encouraging Korean companies to trade and invest in Vietnam. The South Korean administration refused to acknowledge Korean war crimes in Vietnam many years after the conflict. When President Kim Dae-jung visited Hanoi in 1998, he did not apologize or acknowledge the massacres but "expressed regret" concerning the war. ${ }^{92}$ When pressed about the massacres, the government justified them by claiming Korea was then a "sub-empire," exploiting a weaker nation to gain prominence. ${ }^{93}$ The country has tried to repress this criticism by redirecting media coverage to focus on humanitarian aid. By 2002, South Korea built forty new schools and some new hospitals in the areas where massacres against Vietnamese civilians had occurred. ${ }^{94}$

Koreans have resorted to media and literature to absolve the army of its crimes. These fictional representations often glorified Korean soldiers as saviours reluctantly following American orders or precedent. Hwang Suk-Yong's Shadow of Arms cites the Americans as the corrupting source of Korean racism, prostitution, black marketeering in Vietnam, and the civilian massacres' real perpetrators. ${ }^{95}$ White Badge features a Vietnamese perspective of the war, but its movie adaption did not. The film instead centred on a Korean veteran's relationship with Korean society and the Pak regime. ${ }^{96}$ Several other movies, such as R-Point, Sunny, and Ode to My Father, act as revisions of history through American criticism as well. ${ }^{97}$ Finally, Korean atrocities in the Vietnam War were trivialized through music videos like Jo Sung Mo's 2000 “Do You Know," where Korean soldiers sacrifice themselves to save the Vietnamese civilians. Although these stories acknowledge Korean complicity in war crimes, they place most of the

\footnotetext{
92 Lee Kim, "Korea’s Vietnam Question," 631.

${ }^{93}$ Ibid.

${ }^{94}$ Heonik Kwon, After the Massacre, 144.

95 Nguyen, Nothing Ever Dies, 140-141.

${ }^{96}$ Ibid., 144.

${ }^{97}$ Ibid., 149.
} 
blame on American forces and absolve themselves of any actual crime. ${ }^{98}$ The anti-American sentiment within these representations of the Vietnam War worked to re-write South Korea's collective memory of the conflict. However, since many of these movies were not aired outside of Korea, a negative international image of South Korean involvement in Vietnam and a lack of enthusiasm in their "heroism" has persisted. ${ }^{99}$

The South Korean public remain apathetic towards Korean veterans of the Vietnam War. They are ignored by the government and media despite governmental rhetoric about heroism. Settlements for damage caused by Agent Orange are not seriously considered, and veterans were excluded from the 1984 class-action lawsuit undertaken by other allied veterans. ${ }^{100}$ Almost 90,000 veterans were affected by this poison, as they performed ground military operations in the Vietnam rainforest where it was sprayed. ${ }^{101}$ Korean society's indifference towards Vietnam War veterans demonstrates the war's legacy of neglect, especially considering Pak's intense propaganda depicting them as heroes. With the release of information concerning Korean war crimes in Vietnam and the shattering of Pak's image of heroism, the Korean populace chose to ignore Korean involvement in Vietnam and therefore neglected the veterans' sufferings.

\section{Denial and Neglect in Vietnam}

The Vietnamese government is currently seeking economic growth and integration into the global market to maintain its socialist control over the nation. To achieve this end, the Vietnamese government complied with Korean denial, ordering the Vietnamese press not to draw attention to Korean atrocities committed during the war. ${ }^{102}$ The official Vietnamese statement regarding the censorship of Korean atrocities is that "Vietnam must transcend her tragic past, although we must not forget it." ${ }^{103}$ In this way, the Vietnamese government acknowledged the crimes committed during the Vietnam War while avoiding the ire of South Koreans. South Korea is Vietnam's fourth-largest trading partner and fifth-largest foreign investor, with the Daewoo conglomerate hotel in Hanoi being its largest corporate investor. ${ }^{104}$

\footnotetext{
98 Ibid., 151.

${ }^{99}$ Ibid., 143.

100 Armstrong, “America’s Korea,” 537.

${ }^{101}$ Kim, "Penile Necrosis," 545.

${ }^{102}$ Lee Kim, "Korea's Vietnam Question,” 631

${ }^{103}$ Heonik Kwon, After the Massacre, 144.

104 Armstrong, "America's Korea," 537.
} 
Revisiting Korean atrocities could potentially damage the economic relationship between the two countries.

The repression of public memory has also been extended to victimized Vietnamese villages in the form of public memorials. Korean veterans, who apologized to the survivors, offered to pay for the construction of these memorials. Once they were complete, however, the veterans demanded the removal of several inscriptions that labelled past events as 'massacres' by Korean troops, arguing that they wanted a memorial of reconciliation that did not dishonour the dead. ${ }^{105}$ Vietnamese government officials supported the rhetoric of Korean veterans by emphasizing the importance of "transcending their past." 106 In this way, the Vietnamese government contribute to the ongoing neglect and denial of the atrocities committed in the Vietnam War.

\section{Conclusion and Looking Forward}

The legacy of denial and neglect in the Vietnam War has continued to the present day, and the victims of South Korean atrocities have yet to find peace. South Korea's current president, Moon Jae-in, has followed his predecessors' paths in avoiding a direct acknowledgement of Korean war crimes, expressing regret at the "unfortunate history" between Korea and Vietnam in 2018 before a summit meeting with Vietnam. ${ }^{107}$ In April 2019, a petition signed by 103 Vietnamese survivors was issued to the South Korean government, demanding an official acknowledgement of and apology for Korean actions. Additionally, a group of Vietnamese and South Korean lawyers have called for an investigation into the atrocities, reparations for the victims, and the release of military and intelligence records of the incidents. South Korea's failure to take responsibility for its involvement in the Vietnam War has drawn strong criticism from Japan. Despite long condemning Japan for its war crimes in Korea during the Second World War, particularly given Japan's refusal to apologise, South Korea has committed the same offense towards Vietnam. ${ }^{108}$ To overcome its experience of denial and

\footnotetext{
${ }^{105}$ Lee Kim, “Korea’s Vietnam Question,” 624-625.

${ }^{106}$ Heonik Kwon, After the Massacre, 145.

107 Julian Ryall, "Moon Jae-In's Administration Faces Calls to Investigate War Crimes Amid Rising Awareness of South Korea's Atrocities in Vietnam," South China Morning Post, April 18, 2019.

108 Ryall, "Moon Jae-In's Administration."
} 
neglect, South Korea must first acknowledge its actions in Vietnam. Only then can the country begin to make amends with Vietnam and depart from its ongoing legacy of denial and neglect. 


\section{Bibliography}

Armstrong, Charles K. “America’s Korea, Korea's Vietnam.” Critical Asian Studies 33, no. 4 (2001): 527-540

Baek, Glenn. "A Perspective on Korea's Participation in the Vietnam War." The Asian Institute for Policy Studies, no. 53 (2013): 1-9.

Baldwin, Frank. "America's rented troops: South Koreans in Vietnam.” Bulletin of Concerned Asian Scholars 7, no. 4 (1975): 33-40.

Engel, Benjamin A. "Viewing Seoul from Saigon: Withdrawal from the Vietnam War and the Yushin Regime.” The Journal of Northeast Asian History 13, no. 1 (2016): 77-106.

Kim, Jane S. H. "Penile Necrosis, Military Medicine, and South Korean Participation in the Vietnam War, 1964-1973." East Asian Science, Technology and Society: An International Journal 11, no. 4 (2017): 541-561.

Kim, Se Jin. “South Korea’s Involvement in Vietnam and Its Economic and Political Impact." Asian Survey 10, no. 6 (1970): 519-32.

Kwon, Heonik. After the Massacre: Commemoration and Consolation in Ha My and My Lai. Berkeley: University of California Press, 2006.

Lee, Jin-kyung. "Surrogate Military, Subimperialism, and Masculinity: South Korea in the Vietnam War, 1965-73." Positions: East Asia Cultures Critique 17, no. 3 (2009): 655682.

Lee Kim, Hyun Sook. “Korea's Vietnam Question: War Atrocities, National Identity, and Reconciliation." Positions: East Asia Cultures Critique 9, no. 3 (2001): 622-635.

Nguyen, Viet Thanh. Nothing Ever Dies: Vietnam and the Memory of War. Cambridge, Massachusetts: Harvard University Press, 2016.

Ryall, Julian. “Moon Jae-In's Administration Faces Calls to Investigate War Crimes Amid Rising Awareness of South Korea's Atrocities in Vietnam." South China Morning Post, April 18, 2019. https://www.scmp.com/news/asia/east-asia/article/3006771/moon-jae-insadministration-faces-calls-investigate-war-crimes

Seth, Michael J. A Concise History of Korea: From Antiquity to the Present. New York: Rowman \& Littlefield, 2016.

Yi, Kil J. "Alliance in the Quagmire: The United States, South Korea, and the Vietnam War, 1964-1968." PhD diss., University of New-Jersey- New Brunswick, 1997. 